\author{
Jolanta Walas-Trębacz \\ Katedra Procesu Zarządzania \\ Uniwersytet Ekonomiczny w Krakowie
}

\title{
Analiza procesów kształtujących lańcuch wartości przedsiębiorstwa
}

\section{Streszczenie}

W obecnych czasach przedsiębiorstwa są zmuszone określać i zmieniać kreowanie wartości dla klienta. Ważnym etapem w analizie łańcucha wartości przedsiębiorstwa jest identyfikacja procesów realizowanych w przedsiębiorstwie oraz przeprowadzenie ich oceny ze względu na skuteczność i efektywność ich osiągania, co jest możliwe dzięki ustaleniu i opracowaniu określonych miar i sposobów pomiaru wyniku procesów.

Celem opracowania jest przedstawienie jednego ze sposobów zwiększania wartości przedsiębiorstwa, który polega na analizie procesów składających się na łańcuch wartości przedsiębiorstwa. W artykule wyjaśniono podstawowe pojęcia: proces, system procesów oraz zarządzanie procesami, a także zdefiniowano łańcuch wartości i ukazano strukturę kształtujących go procesów.

Zaprezentowano metodykę analizy procesowej, na którą składają się takie etapy, jak: określenie procesów realizowanych w przedsiębiorstwie, wskazanie roli procesów w tworzeniu wartości dodanej dla klienta, pomiar i ocena rezultatów procesów oraz określenie propozycji doskonalenia procesów.

Słowa kluczowe: proces, zarządzanie procesami, metodyka analizy procesowej, łańcuch wartości, struktura łańcucha wartości.

\section{Wprowadzenie}

W warunkach globalizacji gospodarki od innowacyjności działań przedsiębiorstwa oraz atrakcyjności oferty rynkowej zależy ich konkurencyjność. W celu zaspokajania ciągle rosnących potrzeb klientów przedsiębiorstwa powinny dosko- 
nalić zasady i metody funkcjonowania, a przede wszystkim wprowadzać na rynek nowe produkty i usługi, dzięki czemu osiągną większe szanse na sukces rynkowy. Każde przedsiębiorstwo tworzy kompleks działań, których celem jest zaprojektowanie, wytworzenie, sprzedaż na rynku oraz dostarczanie i wspieranie swoich produktów. Wszystkie te działania mogą być zrealizowane za pomocą określonego łańcucha wartości.

$\mathrm{W}$ procesie tworzenia wartości istotne jest właściwe zdefiniowanie kolejnych czynności, w wyniku których realizowana jest wartość na rzecz klientów. Jednym z istotnych narzędzi ukazujących proces „dodawania” wartości do produktu jest łańcuch wartości. Ważnym etapem w przeprowadzaniu analizy łańcucha wartości jest identyfikacja procesów realizowanych w przedsiębiorstwie oraz ocena ich efektywności. Analiza procesów z punktu widzenia ich wpływu na kreowanie wartości dla klienta oraz osiąganą efektywność w przedsiębiorstwie jest podstawową metodą umożliwiającą podejmowanie decyzji prowadzących do poprawy jego funkcjonowania.

Celem niniejszego artykułu jest przedstawienie jednego ze sposobów zwiększania wartości przedsiębiorstwa polegającego na analizie procesów składających się na łańcuch wartości przedsiębiorstwa. W artykule zaprezentowano metodykę analizy procesowej, na którą składają się poszczególne etapy, a mianowicie: identyfikacja procesów realizowanych w przedsiębiorstwie, wskazanie roli procesów w tworzeniu wartości dodanej dla klienta, pomiar i ocena rezultatów procesów oraz określenie kierunków ich doskonalenia.

\section{Pojęcie procesu}

Problematyka procesów wyjaśniana jest na gruncie nie tylko nauki o zarządzaniu, ale także w naukach prawniczych, przyrodniczych czy medycznych ${ }^{1}$. Termin ,proces” wykracza poza tradycyjne odniesienie wyłącznie do procesu produkcyjnego i jest rozumiany jako sekwencja działań realizowanych w celu utrzymania określonego efektu finalnego. Tabela 1 prezentuje wybrane definicje procesu wg różnych autorów.

Ze względu na charakter analizy w opracowaniu proces będzie rozpatrywany jako zintegrowany, celowy układ stanowiący rezultat integracji i strukturalizacji czynności, jak i obiekt zintegrowanego zarządzania. Proces to zbiór działań powiązanych relacjami czasowymi i przestrzennymi ukierunkowany na klientów,

${ }^{1}$ Proces jako kategoria stosowana do analizy działania organizacji wyjaśniany był już przez F.W. Taylora w książce pt.: Zasady naukowego zarzadzania, opublikowanej w 1911 r., ale prawie wyłącznie w odniesieniu do analizy funkcjonalnej i projektowania systemów wytwórczych [Łańcuch tworzenia wartości dodanej, 2007, s. 68]. 
określony przez przepływy materiałów i informacji, przenikający granice poszczególnych sfer działalności przedsiębiorstwa, obejmujący pierwotne i wtórne aktywności tworzące wartość [Logistyka, 2011, s. 97].

Tabela 1. Pojęcie procesu wg różnych autorów

\begin{tabular}{|l|l|}
\hline \multicolumn{1}{|c|}{ Autor } & \multicolumn{1}{c|}{ Definicja procesu } \\
\hline M. Porter & $\begin{array}{l}\text { Proces to łańcuch wartości, w którym poprzez realizację poszczególnych } \\
\text { działań zwiększa się wartość zaangażowania w tworzenie lub dostarcza- } \\
\text { nie produktu lub usługi. Każde kolejne działanie wykonywane w proce- } \\
\text { sie powinno dodawać nową wartość do efektu wcześniejszej czynności. }\end{array}$ \\
\hline $\begin{array}{l}\text { M. Hammer, } \\
\text { J. Champy } \\
\text { stwa, a wykonywanych w celu dostarczenia klientowi konkretnej usługi } \\
\text { lub produktu. }\end{array}$ \\
\hline $\begin{array}{l}\text { R. Muller, } \\
\text { P. Rupper }\end{array}$ & $\begin{array}{l}\text { Proces to łańcuch działań zmierzający do wytworzenia wartości odpo- } \\
\text { wiadających wymaganiom klienta. }\end{array}$ \\
\hline B. Olszewska & $\begin{array}{l}\text { Proces to zestaw działań i zadań z jasno określonymi elementami na wej- } \\
\text { ściu oraz wyjściu, a jego rezultatem jest wartość oferowana klientowi. }\end{array}$ \\
\hline P. Blaik & $\begin{array}{l}\text { Proces to sekwencja lub częściowo uporządkowany zbiór powiązanych } \\
\text { ze sobą działań zintegrowanych przez: czas, koszty, łączną ocenę wyko- } \\
\text { nania i realizowanych, aby osiągnąć określony cel organizacji. }\end{array}$ \\
\hline $\begin{array}{l}\text { G. Rummler, } \\
\text { A. Brache }\end{array}$ & $\begin{array}{l}\text { Proces to ciąg czynności zaprojektowanych, a następnie wykonywanych } \\
\text { w ten sposób, aby w ich wyniku powstał produkt lub usługa. }\end{array}$ \\
\hline $\begin{array}{l}\text { R. Kaplan, } \\
\text { D. Norton }\end{array}$ & $\begin{array}{l}\text { Procesy w organizacji to kreowanie wartości, która przyciągnie } \\
\text { i zatrzyma klientów do celowego segmentu oraz zapewni spełnienie ocze- } \\
\text { kiwań akcjonariuszy odnośnie do wyników finansowych organizacji. }\end{array}$ \\
\hline
\end{tabular}

Źródło: opracowanie własne na podstawie: [Porter 1985, s. 3; Hammer i Champy 1996; Muller i Rupper 2000, s. 21; Olszewska 2003, s. 296; Blaik 2001, s. 111-113; Rummler i Brache 2000, s. 75; Kaplan i Norton 2001, s. 43].

W przedsiębiorstwie zmiany następują w szerszym środowisku, którym jest system procesów. Stanowi on zespół współdziałających ze sobą procesów, których zadaniem jest tworzenie wartości dodanej dla klienta. Zarządzanie procesami to dziedzina zajmująca się analizą, standaryzacją, planowaniem i zarządzaniem istniejącymi procesami w organizacji. Zdaniem J. Brilmana, zarządzanie procesami polega na dokonywaniu systematycznej oceny ich efektów, podtrzymywaniu ich funkcjonowania i wprowadzaniu korekt, jeśli osiągane rezultaty odbiegają od normy [Brilman 2002, s. 293].

W niniejszym artykule analiza procesów będzie dotyczyć wewnętrznego łańcucha wartości przedsiębiorstwa, ale należy także pamiętać, że na wartość dodaną będą miały wpływ także procesy występujące w łańcuchach dostawców, kooperantów czy odbiorców. 


\section{Procesy w łańcuchu wartości przedsiębiorstwa}

Łańcuch wartości (value chain) jest uporządkowanym ciągiem różnego rodzaju funkcji generujących wartość produktu, która jest określona przez relacje rynkowe między firmą a nabywcą; jest ciągiem powiązanych ze sobą (szeregowo lub równolegle) faz procesu zarządzania i procesów wykonawczych, odniesionych do określonego sektora działalności firmy. To sekwencja funkcji danego systemu, np. przedsiębiorstwa lub szerszego układu kooperacyjnego mającego rozwinięte relacje zewnętrzne [Stabryła 2007, s. 165].

Model łańcucha wartości przedstawił w 1985 r. M.E. Porter ${ }^{2}$. Ujął go w formę schematu, na którym została nakreślona w sposób bardzo ogólny struktura powiązanych ze sobą procesów głównych i pomocniczych, jakie występują w przedsiębiorstwie. Łańcuch wartości według M.E. Portera to narzędzie rozpoznawania sposobów tworzenia większej wartości dla klienta, z pozycji przedsiębiorstwa, którego celem jest maksymalizacja wartości dodanej (zysku).

Każde przedsiębiorstwo jest więc jednym z ogniw systemu wartości (rys. 1), a z drugiej zaś strony tworzy własny wewnętrzny łańcuch wartości (rys. 2).

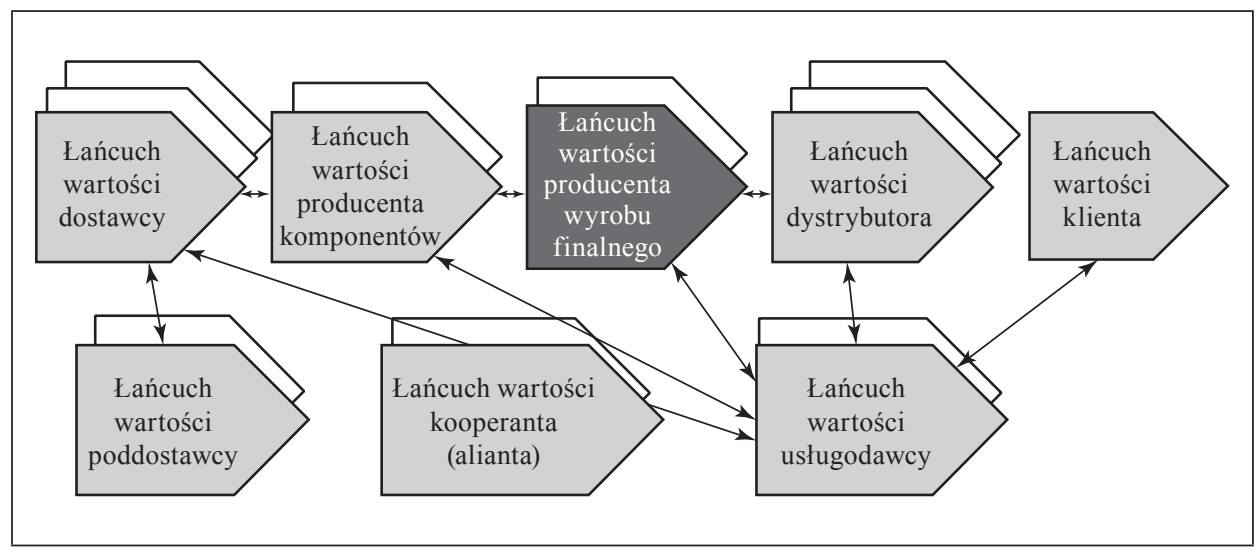

Rys. 1. System wartości

Źródło: opracowanie własne.

${ }^{2}$ Koncepcja łańcucha wartości, nazywanego również łańcuchem ekonomicznym [Drucker 1976, s. 120], jest ściśle związana z wartością dodaną, powstającą w kolejnych ogniwach procesów gospodarczych. Charakteryzuje ona przyrost wartości produktów (towarów), a zarazem kształtowanie się kosztów w przedsiębiorstwie [Stabryła 2006, s. 363]. 


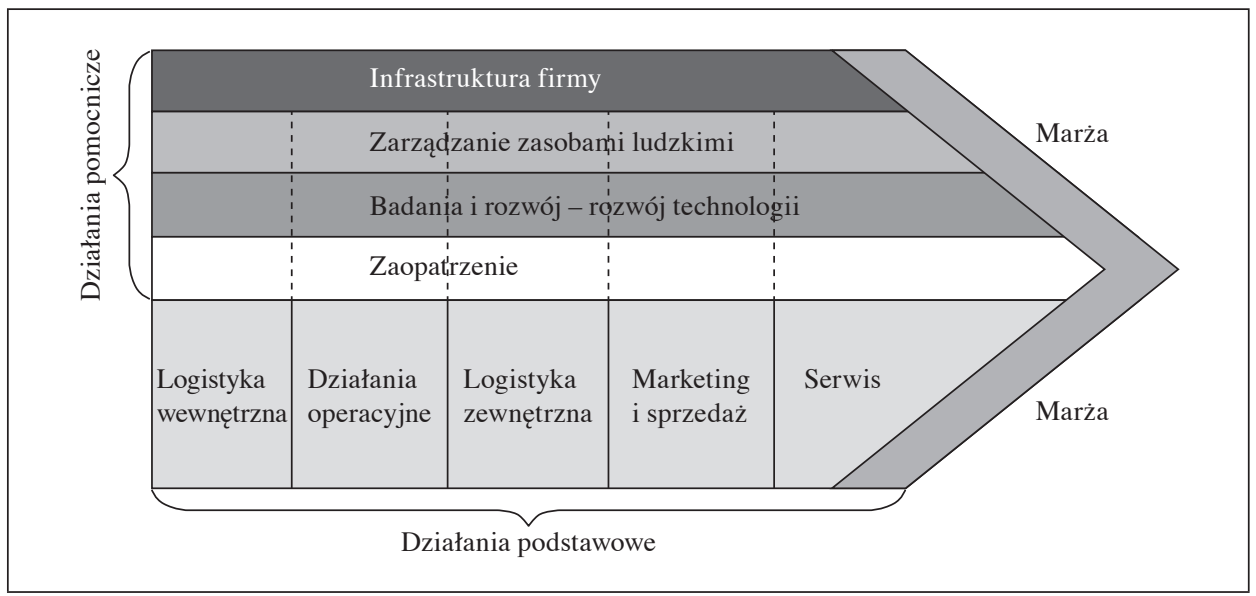

Rys. 2. Łańcuch wartości przedsiębiorstwa jako sekwencja procesów podstawowych i pomocniczych

Źródło: [Porter 2006, s. 65].

Rys. 3. prezentuje przykład podmiotowej struktury łańcucha wartości w branży odzieżowej.

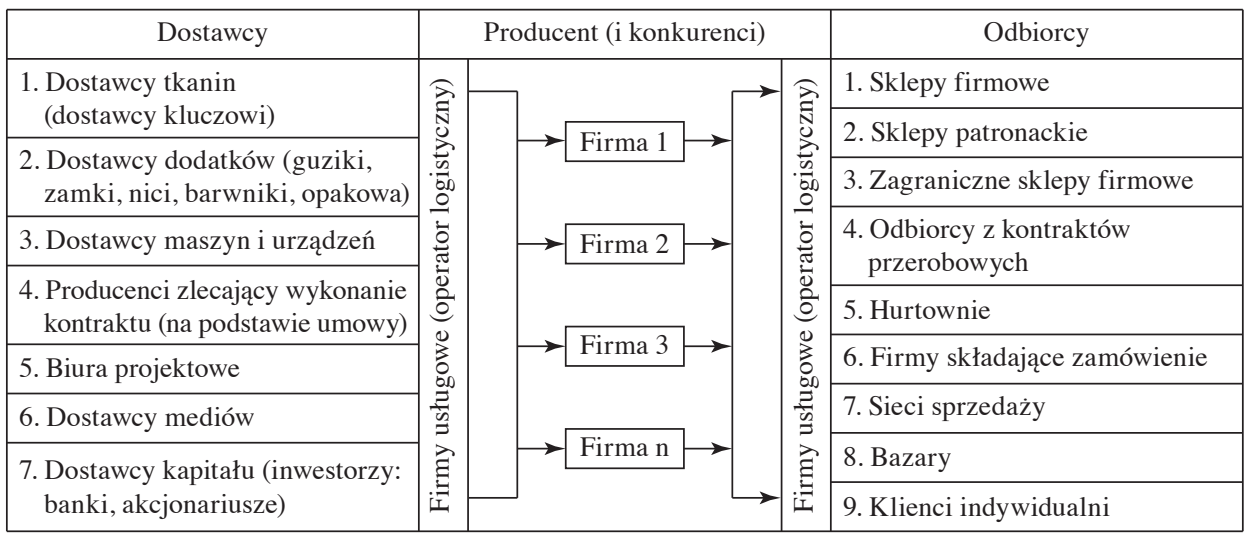

Rys. 3. Podmiotowa struktura łańcucha wartości w branży odzieżowej

Źródło: opracowanie własne.

W zależności od sektora w tworzeniu łańcucha wartości może uczestniczyć wiele podmiotów ${ }^{3}$. Najprostszy łańcuch wartości obejmuje: dostawców, produ-

${ }^{3}$ Sektor jest układem, który wiąże w całość dane przedsiębiorstwo z jego dostawcami, dystrybutorami i klientami. 
centów, klientów. Rozbudowany zaś łańcuch wartości zawiera dodatkowo trzy typy uczestników: „dostawcy dostawców” (tzw. poddostawcy), „klienci klientów” (znajdujący się na samym końcu łańcucha) [Strategiczne zarzadzanie kosztami, 2006, s. 108] oraz firmy świadczące usługi dla innych firm objętych łańcuchem wartości.

Ważnym zadaniem w procesie analizy łańcucha wartości jest określenie struktury łańcucha wartości dla całego sektora, czyli rozpoznanie działań tworzących ścieżkę ekonomiczną związaną z wytwarzaniem określonego produktu [Gierszewska i Romanowska 2003, s. 184]. Podstawą osiągnięcia przewagi konkurencyjnej jest zrozumienie całego sektora, w którym przedsiębiorstwo konkuruje, nie zaś tylko tej części systemu wartości, w której partycypuje.

Na rys. 4 przedstawiono łańcuch wartości w sektorze napojów gazowanych (oranżada, cola, woda mineralna), aby ukazać różną partycypację w zestawie działań przyczyniających się do wytworzenia i sprzedaży napojów oraz różny poziom integracji pionowej uczestników sektora.

Na rys. 4 wyodrębniono siedem podstawowych działań, których wykonywanie pozwala temu sektorowi dostarczać napoje indywidualnym klientom. Łańcuch wartości rozpoczyna się już w momencie pozyskiwania (wydobywania), a następnie uszlachetniania wody niezbędnej do produkcji napojów. Głównym działaniem jest przygotowanie syropu, który jest w odpowiednich proporcjach mieszany z wodą. Tak powstały napój zostaje w procesie rozlewania nasycony dwutlenkiem węgla i ostatecznie zapakowany do butelek. Końcowe etapy działań w łańcuchu wartości dotyczą przekazania wyprodukowanych napojów do kanałów dystrybucji, a później do klientów. Należy podkreślić, że przedsiębiorstwa działające w sektorze napojów gazowanych mogą w różnym zakresie partycypować w zestawie działań wyodrębnionych w łańcuchu wartości, czyli ich poziom integracji pionowej może być odmienny. Litery od A do $\mathrm{H}$ reprezentują podmioty działające w sektorze, które mogą być w pełni zintegrowane tak jak przedsiębiorstwo E (posiadające ujęcie wody pitnej, wytwarzające napoje i dysponujące siecią dystrybucji), natomiast przedsiębiorstwo A zajmuje się wyłącznie rozlewaniem napojów. Pozostałe przedsiębiorstwa konkurują, prowadząc działalność w dwóch do czterech ogniwach ścieżki ekonomicznej. Oznacza to, że każde z nich ma unikalny wewnętrzny łańcuch wartości, który obejmuje inny zestaw działań. Tak więc rozpoznanie miejsca danego przedsiębiorstwa w całym systemie wartości jest kluczowe z punktu widzenia określenia jego pozycji konkurencyjnej i potencjalnych źródeł przewagi (przykładowo przedsiębiorstwo B jest dostawcą dla przedsiębiorstwa G, które zajmuje się tylko pakowaniem i dystrybucją, a jednocześnie jest nabywcą przedsiębiorstwa $\mathrm{C}$, które wydobywa i uszlachetnia wodę) [Strategiczne zarzadzanie kosztami, 2006, s. 116-117]. 


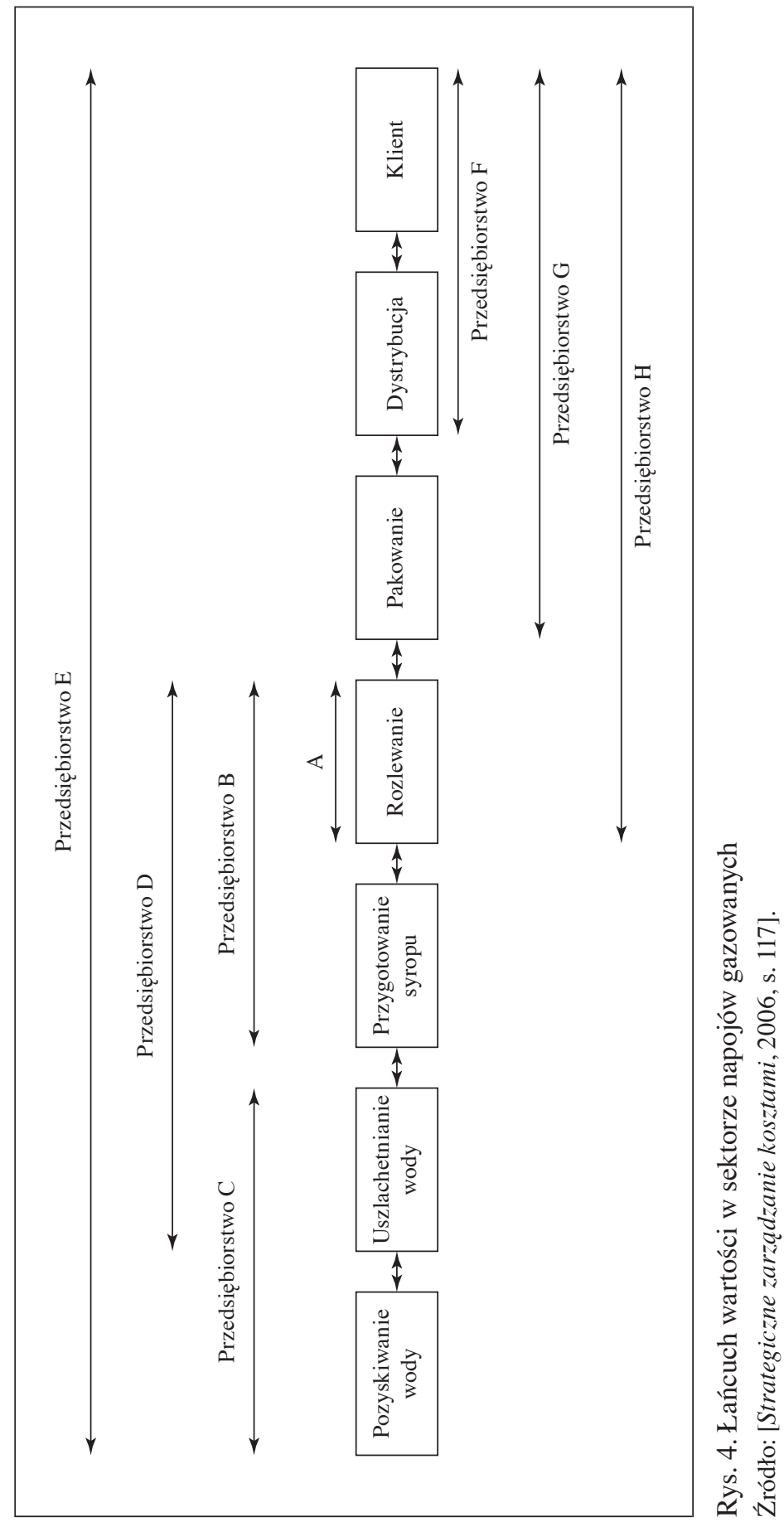


Kluczem do zrozumienia istoty łańcucha wartości jest pojęcie wartości ${ }^{4}$. M. Porter wartość rozumie jako sumę, którą nabywca gotów jest zapłacić za to, czego dostarcza mu dostawca. System wartości zaś opisuje ciąg działań i przedsiębiorstw realizujących te działania, zmierzający do dostarczenia użytkownikowi finalnemu wartości użytkowych, których oczekuje. Obejmuje więc takie wartości, jak: dostawców, producentów, dystrybutorów i użytkowników (klientów) [Lisiecka i Czakon 2002, s. 386].

Przewaga konkurencyjna przedsiębiorstwa jest więc rezultatem różnorakich działań realizowanych podczas projektowania, produkcji, marketingu czy w funkcjach je wspomagających. Każde z tych działań może w swoisty sposób kształtować wielkość kosztów, jak również tworzyć wartość dodaną. Analizując poszczególne „ogniwa” łańcucha wartości, można określić miejsca, w których ta wartość powstaje w stopniu najwyższym lub miejsca, w których powstają straty. Identyfikacja i analiza łańcucha wartości to sposób na poszukiwanie źródeł sprawności i niesprawności przedsiębiorstwa, a przede wszystkim obszarów działań, w których przedsiębiorstwo dysponuje szczególnymi kompetencjami wytwórczymi, technologicznymi, organizacyjnymi, informacyjnymi, kooperacyjnymi, mogącymi się stać źródłem przewagi konkurencyjnej.

Takie podejście oznacza, że przedsiębiorstwo powinno stanowić centrum działań. Efektem końcowym procesu jest wartość produktu lub usługi akceptowana przez klienta. Przyjęcie takiego podejścia w przedsiębiorstwie powoduje, że powinno ono starannie i systematycznie zarządzać wszystkimi procesami, które biorą udział w tworzeniu wartości dla klienta [Edwards, Braganza i Lambert 2000, s. 29]. Wyniki, jakie są osiągane w każdym procesie, można rozpatrywać w aspekcie skuteczności i efektywności takiego procesu ${ }^{5}$.

Identyfikacja struktury łańcucha wartości stanowi początkowy etap jego analizy i szacowania wartości dodanej, tworzonej w poszczególnych ogniwach i w łańcuchu jako całości. Precyzyjne określenie rzeczywistej struktury łańcucha wartości jest w praktyce bardzo trudne, gdyż struktura ta jest dynamiczna i ulega ciągłym zmianom, zwłaszcza jeśli przedsiębiorstwo może uczestniczyć w kilku łańcuchach (w różnych sektorach) albo w tzw. sieciach łańcucha, gdzie jego udział w tworzeniu wartości dodanej może być zróżnicowany (np. w jednym łańcuchu wartości pełni rolę koordynatora, w kolejnym - rolę integratora, a jeszcze w innym - rolę specjalisty). Wchodząc do różnych sieci, zmieniają się także granice łańcucha wartości przedsiębiorstwa. W wyniku coraz ściślejszych powiązań partnerskich

${ }^{4}$ Wartość odnosi się do poszczególnych ogniw łańcucha i wyraża bądź wynik końcowy, czyli zysk, bądź efekty pośrednie, ale może odnosić się do kosztów, jakie są generowane we wszystkich stadiach określonego procesu [Stabryła 2007, s. 165-166].

5 Skuteczność procesu to zdolność do osiągniecia celów, natomiast efektywność procesu to relacja między wynikami a wykorzystanymi zasobami w procesie [Skrzypek i Hofman 2010, s. 14]. 
firm z klientami, z dostawcami, granice zewnętrzne tych firm stają się bardziej płynne, co wiąże się z upowszechnieniem i rozwojem sieci informatycznych i powoduje powstawanie firm sieciowych czy wirtualnych [Brilman 2002, s. 425] ${ }^{6}$.

\section{Metodyka analizy procesów kształtujących łańcuch wartości przedsiębiorstwa}

Koncepcja przedsiębiorstwa zorganizowanego w sposób procesowy sięga lat 50. XX w. Procesowe podejście miało jednak wtedy inny wymiar. Wykorzystane było bowiem do strukturalizacji i formalizacji zarządzania produkcją. Obecnie zarządzanie procesowe ma zapewnić większą efektywność wszystkich działań, których rezultatem jest wzrost wartości dla klienta [Sopińska 2004, s. 52]. Dlatego zrozumienie roli i oczekiwań klienta stanowi bardzo ważny element we wdrożeniu zarówno podejścia procesowego, jak i działań zmierzających do poprawy efektywności organizacji. Głównym celem procesów jest maksymalizacja satysfakcji klienta. Podejście procesowe do zarządzania firmą pozwala w większym stopniu uwzględnić potrzeby klientów w działalności przedsiębiorstwa. Klient nie jest bowiem zainteresowany tym, co się dzieje wewnątrz organizacji; nie interesuje go ani struktura organizacyjna, ani cele strategiczne przedsiębiorstwa, lecz wartość, jaka jest mu oferowana. Dobre zarządzanie procesami powinno polegać na „identyfikowaniu potrzeb najważniejszych klientów i próby ich zaspokojenia” [Brilman 2002, s. 296], ,,myślenie w kategoriach procesów pozwala poszukiwać źródeł wartości dla klientów" [Sopińska 2004, s. 52].

Procesowa analiza przedsiębiorstwa powinna zatem obejmować następujące etapy:

1) identyfikację i hierarchizację procesów realizowanych w przedsiębiorstwie,

2) określenie roli procesów w tworzeniu wartości dodanej dla klienta,

3) pomiar i ocenę rezultatów procesów,

4) propozycje doskonalenia procesów [Biazzo i Bernardi 2003, s. 154-156]7.

${ }^{6}$ Przedsiębiorstwo może prowadzić działalność w różnych sektorach, dlatego też ważne jest określenie granic dla każdego łańcucha wartości z osobna. W każdym z łańcuchów wartości może zajmować różne pozycje, odgrywać różną rolę, wykorzystywać odmienne zasoby i kompetencje, stosować odmienne strategie konkurowania, a także osiągać inny poziom wartości dodanej z funkcjonowania w określonym sektorze itp. Granice stanowią istotną składową przedsiębiorstwa i determinują one możliwość prawidłowego definiowania aktywności organizacji i zachowań jej uczestników [Cyfert 2012, s. 17]. Należy także pamiętać, że granice przedsiębiorstwa mogą ulegać zmianie wraz z wchodzeniem przez nie w różnego typu relacje kooperacyjne.

${ }^{7}$ Metodyka zarządzania procesowego jest szerzej przedstawiona w opracowaniach: [Zarządzanie procesami biznesowymi, 2009, s. 48-51; Bitkowska i in. 2011 s. 43-48]. 
Etap 1. Określenie sprawności całego systemu wymaga dokładnej analizy sprawności poszczególnych procesów występujących w przedsiębiorstwie. Typowymi elementami każdego procesu w przedsiębiorstwie są: nazwa powiązana z zakresem działalności przedsiębiorstwa, podstawowe cele procesu, kategoria oczekiwanego lub pożądanego wyniku i jego odbiorcy, warunki wstępne realizacji procesu, główni uczestnicy procesu, reguły inicjacji procesu, składowe działań procesu oraz miary poprawności realizacji procesu i prawidłowości wyniku [Logistyka, 2011, s. 141] ${ }^{8}$.

W pierwszym etapie analizy należy określić procesy główne oraz procesy pomocnicze powiązane ze sobą relacjami następstwa lub równoległości oraz relacjami czasowymi i logicznymi. Dużym ułatwieniem w precyzowaniu szczegółów jest odwołanie się do szablonu struktury prezentacji procesu (tabela 2).

Tabela 2. Przykładowy schemat struktury prezentacji procesu dostaw do klienta w firmie dystrybucyjnej

\begin{tabular}{|c|l|l|}
\hline Grupa składowych & \multicolumn{1}{|c|}{$\begin{array}{c}\text { Specyfikacja } \\
\text { składowych procesu }\end{array}$} & \multicolumn{1}{|c|}{ Wyszczególnienie } \\
\hline $\begin{array}{c}\text { 1. Wskazania identyfi- } \\
\text { kujące proces }\end{array}$ & 1. Nazwa procesu & Realizacja dostawy do klienta \\
\cline { 2 - 3 } & 2. Cel procesu & $\begin{array}{l}\text { Niezawodność realizacji zamówienia klienta } \\
\text { Utrzymanie racjonalnych zapasów } \\
\text { Organizacja taniego, szybkiego i pewnego } \\
\text { transportu }\end{array}$ \\
\cline { 2 - 4 } & $\begin{array}{l}\text { 3. Główni uczestnicy } \\
\text { procesu }\end{array}$ & $\begin{array}{l}\text { Klienci } \\
\text { Dostawcy } \\
\text { Przewoźnicy } \\
\text { Dział Logistyki } \\
\text { Dział Obsługi Klienta } \\
\text { sagazyn }\end{array}$ \\
\hline 2. Informacje o wej- & $\begin{array}{l}\text { 4. Warunki wstępne } \\
\text { rozpoczęcia pro- } \\
\text { cesu }\end{array}$ & $\begin{array}{l}\text { Poziom zapasów spełnia wymagania przewidy- } \\
\text { wane sezonowości } \\
\text { Dostawcy są gotowi do szybkiego uzupełniania } \\
\text { zapasów }\end{array}$ \\
\cline { 2 - 4 } & $\begin{array}{l}\text { 5.Zdarzenie inicju- } \\
\text { jące proces }\end{array}$ & Złożenie zamówienia przez klienta \\
\cline { 2 - 4 } & $\begin{array}{l}\text { 6. Inicjator procesu } \\
\text { 7. Miejsce rozpoczę- } \\
\text { cia procesu i wska- } \\
\text { zanie właściciela } \\
\text { procesu }\end{array}$ & Klient \\
\hline \multirow{2}{*}{ Dział Obsługi Klienta - pracownik Działu }
\end{tabular}

${ }^{8}$ Zakres identyfikacji i poziom szczegółowości informacji o procesach zależy od potrzeb decyzyjnych przedsiębiorstwa [Nowak, Piechota i Wierzbiński 2004]. 
cd. tabeli 2

\begin{tabular}{|c|c|c|}
\hline \multirow[t]{3}{*}{ Grupa składowych } & $\begin{array}{l}\text { Specyfikacja } \\
\text { składowych procesu }\end{array}$ & Wyszczególnienie \\
\hline & 8. Obiekt na wejściu & Lista pozycji z zamówienia klienta \\
\hline & $\begin{array}{l}\text { 9. Postać obiektu } \\
\text { wejściowego }\end{array}$ & $\begin{array}{l}\text { Zamówienie klienta (faks lub e-mail, telefo- } \\
\text { niczne) }\end{array}$ \\
\hline \multirow[t]{3}{*}{$\begin{array}{l}\text { 3. Charakterystyki } \\
\text { przebiegu procesu }\end{array}$} & $\begin{array}{l}\text { 10. Reguły transfor- } \\
\text { macji } \\
\text { (Opis działań) }\end{array}$ & $\begin{array}{l}\text { 1. Sprawdzenie poprawności zamówienia } \\
\text { klienta } \\
\text { 2. Sprawdzenie poziomu zapasów i działania } \\
\text { A. Zapasy wystraczające do realizacji zamó- } \\
\text { wienia: } \\
\text { - przekazanie listy zamówienia klienta do } \\
\text { komisjonowania } \\
\text { - przygotowanie wysyłki do klienta } \\
\text { - kontakt z przewoźnikiem i ustalenie terminu } \\
\text { załadunku } \\
\text { - załadunek i transport do klienta } \\
\text { B. Zapasy są niewystarczające do realizacji } \\
\text { zamówienia klienta: } \\
\text { - kontakt z dostawcą i złożenie zamówienia } \\
\text { uzupełniającego zapasy } \\
\text { - uzyskanie potwierdzenia o warunkach } \\
\text { dostawy od dostawcy (termin, cena) } \\
\text { - kontakt z przewoźnikiem i uzgodnienie } \\
\text { warunków dokonania przewozu } \\
\text { - uzgodnienie między dostawcą, przewoź- } \\
\text { nikiem i magazynem terminu realizacji } \\
\text { dostawy } \\
\text { - przygotowanie do przyjęcia dostawy } \\
\text { - przyjęcie dostawy i jej komisjonowanie zgod- } \\
\text { nie z zamówieniem klienta } \\
\text { - kontakt z przewoźnikiem i uzgodnienie ter- } \\
\text { minu wysyłki do klienta } \\
\text { - powiadomienie klienta o przewidywanym } \\
\text { terminie } \\
\text { - dostawa do klienta }\end{array}$ \\
\hline & $\begin{array}{l}\text { 11. Wymagana infra- } \\
\text { struktura procesu }\end{array}$ & $\begin{array}{l}\text { Łącza faksowe, telefoniczne, internetowe } \\
\text { Komputery, oprogramowanie, system informa- } \\
\text { tyczny wspomagający zarzadzanie firmą } \\
\text { Magazyn środki transportu } \\
\text { Pracownicy o odpowiednich kwalifikacjach }\end{array}$ \\
\hline & $\begin{array}{l}\text { 12. Warunki realizacji } \\
\text { i ograniczenia }\end{array}$ & $\begin{array}{l}\text { Długi termin realizacji dla produktów, których } \\
\text { nie ma na stanie magazynowym } \\
\text { Ograniczenie dni wykonywania usługi (dwa dni } \\
\text { w tygodniu przez firmy spedycyjne) }\end{array}$ \\
\hline
\end{tabular}


cd. tabeli 2

\begin{tabular}{|c|c|c|}
\hline Grupa składowych & $\begin{array}{c}\text { Specyfikacja } \\
\text { składowych procesu }\end{array}$ & Wyszczególnienie \\
\hline & & $\begin{array}{l}\text { Mała elastyczność dostawców do zmian wcze- } \\
\text { śniej potwierdzonych terminów, asortymentu } \\
\text { i ilości }\end{array}$ \\
\hline & 13. Wyjątki & Dostawa do klienta priorytetowego \\
\hline & $\begin{array}{l}\text { 14. Obiekt monitoro- } \\
\text { wania }\end{array}$ & $\begin{array}{l}\text { Status zamówień klientów } \\
\text { Realizacja transportu }\end{array}$ \\
\hline & 15. Wynik procesu & Dostaw do klienta \\
\hline & 16. Postać procesu & Potwierdzenie przyjęcia dostawy przez klienta \\
\hline & $\begin{array}{l}\text { 17. Miejsce powstania } \\
\text { wyniku }\end{array}$ & $\begin{array}{l}\text { Miejsce przyjęcia dostawy przez klienta } \\
\text { System informatyczny rejestrujący obsługę } \\
\text { klienta }\end{array}$ \\
\hline & 18. Odbiorca wyniku & $\begin{array}{l}\text { Klient (otrzymuje potwierdzenie zamówienia) } \\
\text { Dział Logistyki (informacja o stanie zapasów } \\
\text { magazynowych) }\end{array}$ \\
\hline \multirow[t]{2}{*}{$\begin{array}{l}\text { 4. Zakończenie } \\
\text { procesu }\end{array}$} & $\begin{array}{l}\text { 19. Sposób przekaza- } \\
\text { nia wyniku }\end{array}$ & $\begin{array}{l}\text { Klient: telefonicznie, faksem, e-mailem } \\
\text { Dział Logistyki: komunikat systemowy o stanie } \\
\text { zapasów }\end{array}$ \\
\hline & $\begin{array}{l}\text { 20. Dokumentacja } \\
\text { zakończenia } \\
\text { procesu }\end{array}$ & $\begin{array}{l}\text { Zapis w rejestrze zrealizowanych dostaw } \\
\text { Dokument Wz - wydanie z magazynu } \\
\text { Faktura do zapłaty } \\
\text { Dokument Pz (przyjęcie zewnętrzne) - protokół } \\
\text { odbioru }\end{array}$ \\
\hline
\end{tabular}

Źródło: opracowane na podstawie: [Logistyka, 2011 s. 142-144].

W trakcie wypełniania karty opisu procesu następuje wnikliwa analiza istotnych parametrów i spostrzeżenia związane z możliwościami wprowadzenia zmian w istniejącym procesie. Oprócz dokonania strukturalizacji procesu ważne jest stworzenie mapy (macierzy) odpowiedzialności z uwzględnieniem komórek uczestniczących w działaniach i ich roli. Najpowszechniejszymi formami przedstawiania modelu procesu są prezentacje graficzne w postaci: diagramu (który pozwala uwidocznić jednostki zaangażowane w proces, transfery między działaniami i następstwa w czasie) oraz mapy procesów (która pozwala na ukazanie istniejącej struktury procesów w przedsiębiorstwie, wskazanie właścicieli procesów oraz odpowiednich miar oceny sprawności procesów) [Kale 2001, s. 139]. Po ustaleniu hierarchicznej struktury procesów możliwe jest określenie koncepcji systemu mierzenia efektywności procesów.

Etap 2. W kolejnym etapie analizy wyróżnione procesy realizowane w przedsiębiorstwie powinny być ocenione z punktu widzenia ich wpływu na tworzenie 
wartości dodanej. Ze względu na wartość, jaką generują procesy dla klienta, można je podzielić na:

- procesy podstawowe (procesy, które bezpośrednio wiążą się z tworzeniem wartości dla klienta, mają one strategiczne znaczenie i zazwyczaj przebiegają przez wiele działów tradycyjnej organizacji oraz „wiążą” dostawców z klientami. Do tych procesów zalicza się: marketing i obsługę klienta, projektowanie, techniczne przygotowanie i organizację produkcji, zakupy, wytwarzanie, dystrybucja, świadczenie usług);

- procesy pomocnicze (procesy, które wspierają działalność podstawową i są dla jej skutecznej i prawidłowej realizacji uważane jako niezbędne. Do tych procesów zaliczyć można np.: wytwarzanie narzędzi, transport wewnętrzny, kontrolę jakości, magazynowanie, konserwację i utrzymanie ruchu maszyn i urządzeń, infrastrukturę, personel);

- procesy zarządcze (to procesy informacyjno-decyzyjne - aspekt dynamiczny, które przebiegają w określonej strukturze organizacyjnej przedsiębiorstwa aspekt statyczny). Do tych procesów zalicza się: zarządzanie strategią, zarządzanie finansami, zarządzanie informacjami [Skrzypek, Hofman 2010, s. 68-75].

Według innej klasyfikacji procesów wyróżniono procesy strategiczne, operacyjne oraz procesy umożliwiające inne działania. Niezależnie od przyjętego wcześniej podziału procesów w przedsiębiorstwie ze względu na problematykę zarządzania procesami (działaniami) ważne jest ich sklasyfikowanie na procesy (działania):

- zwiększające wartość dla klienta (value-added, VA) to działania, w wyniku których powstaje produkt o cechach pożądanych przez klienta oraz wymagany przez klienta sposób obsługi,

- niezwiększające wartości dla klienta (nonvalue-added, NVA) to działania, których wykonywanie nie przyczynia się do powstawania produktów i usług mających wartość dla klienta.

Tabela 3 ukazuje przykładowe procesy i związane z nimi działania, które tworzą i nie tworzą wartości dodanej.

Tabela 3. Przykłady procesów tworzących i nietworzących wartości dodanej

\begin{tabular}{|l|c|c|}
\hline \multicolumn{1}{|c|}{ Procesy } & $\begin{array}{c}\text { Działania (czynności) tworzące } \\
\text { wartość dodaną }\end{array}$ & $\begin{array}{c}\text { Działania (czynności) nietworzące } \\
\text { wartości dodanej }\end{array}$ \\
\hline $\begin{array}{l}\text { 1. Wprowadzenie } \\
\text { zamówienia do } \\
\text { systemu przedsię- } \\
\text { biorstwa }\end{array}$ & $\begin{array}{l}\text { - dostarczanie właściwej doku- } \\
\text { mentacji }\end{array}$ & $\begin{array}{l}\text { - przerwanie prac nad zamówie- } \\
\text { niem }\end{array}$ \\
& $\begin{array}{l}\text { złożenie obietnicy dotyczącej } \\
\text { czalealizacji zamówienia } \\
\text { zamówie procesu realizacji }\end{array}$ & - kopiowanie zamówienia \\
& \\
\hline
\end{tabular}


cd. tabeli 3

\begin{tabular}{|c|c|c|}
\hline Procesy & $\begin{array}{c}\text { Działania (czynności) tworzące } \\
\text { wartość dodaną }\end{array}$ & $\begin{array}{c}\text { Działania (czynności) nietworzące } \\
\text { wartości dodanej }\end{array}$ \\
\hline $\begin{array}{l}\text { 2. Kreowanie kon- } \\
\text { cepcji produktu }\end{array}$ & $\begin{array}{l}\text { - tworzenie produktu na zamówie- } \\
\text { nie klienta } \\
\text { - usprawnianie istniejących pro- } \\
\text { duktów mające na celu: obni- } \\
\text { żenie kosztów, podniesienie } \\
\text { jakości, udoskonalenie wzorców, } \\
\text { skrócenie czasu wykonania } \\
\text { - standaryzacja } \\
\text { - analiza wartości }\end{array}$ & $\begin{array}{l}\text { - projektowanie już istniejących } \\
\text { komponentów } \\
\text { - tworzenie zbyt szczegółowych } \\
\text { specyfikacji } \\
\text { - projektowanie niepotrzebnych } \\
\text { opcji } \\
\text { - powielanie istniejącej części } \\
\text { projektu }\end{array}$ \\
\hline 3. Zakupy & - proces realizacji dostawy & $\begin{array}{l}\text { - czynności transportowe } \\
\text { u odbiorcy } \\
\text { - inspekcje } \\
\text { - prace biurowe } \\
\text { - przeliczanie części } \\
\text { - czas w doku załadunkowo-wyła- } \\
\text { dunkowym }\end{array}$ \\
\hline 4. Produkcja & - proces produkcji & $\begin{array}{l}\text { - poprawianie wadliwych produk- } \\
\text { tów } \\
\text { - produkcja odpadów } \\
\text { - oczekiwanie na następną czyn- } \\
\text { ność }\end{array}$ \\
\hline 5. Pakowanie & $\begin{array}{l}\text { - pakowanie zapewniające ochronę } \\
\text { przed zniszczeniem w czasie } \\
\text { transportu }\end{array}$ & $\begin{array}{l}\text { - wewnętrzne czynności transpor- } \\
\text { towe } \\
\text { - inspekcja końcowa }\end{array}$ \\
\hline
\end{tabular}

Źródło: [Handfield 1995, s. 5].

Etap 3. Kolejnym istotnym etapem w analizie procesowej jest pomiar wyników poszczególnych procesów. Wszystkie procesy realizowane w przedsiębiorstwie należy przejrzeć pod względem ich ekonomicznej efektywności, czyli relacji ponoszonych nakładów i efektów działania (np. koszt wytworzenia jednego produktu). Jeżeli relacje nie mogą zostać wyrażane w mierniku pieniężnym, to wykorzystać można mierniki niefinansowe (np. czas produkcji lub obsługi klienta).

Do oceny procesu można także wykorzystać miary skuteczności, tj. stopień osiągnięcia założonego celu (np. procent dostaw na czas lub udział pracowników wykorzystujących określony system wspomagający zarządzanie). Procesy realizowane w przedsiębiorstwie można zatem podzielić w zależności od wpływu na subiektywnie postrzeganą przez klienta wartość oraz z uwagi na efektywność wykonywania. Najbardziej pożądanym stanem są procesy, które zwiększają wartość dla klienta i są wykonywane efektywnie. 
Jedną z istotnych decyzji w obszarze zarządzania procesami jest wybór mierników oceny procesów. Tabela 4 prezentuje przykładowy zestaw mierników dla wybranych procesów.

Tabela 4. Przykładowy zestaw mierników dla wybranego procesu podstawowego, pomocniczego i zarządczego $\mathrm{w}$ przedsiębiorstwie

\begin{tabular}{|c|c|}
\hline Rodzaj procesu & Miernik oceny procesu \\
\hline \multicolumn{2}{|r|}{ Pomiar wyników procesu podstawowego } \\
\hline $\begin{array}{l}\text { Projektowanie } \\
\text { produktów }(\mathrm{B}+\mathrm{R})\end{array}$ & $\begin{array}{l}\text { - ilość i jakość projektowanych wyrobów, technologii } \\
\text { - zakres i możliwości przeprojektowania produktów } \\
\text { - czas i koszt opracowania nowego produktu } \\
\text { - czas cyklu wprowadzania nowych produktów } \\
\text { - zakres i tempo wprowadzania zmian w produkcie } \\
\text { - czas cyklu weryfikacji projektów konstrukcyjnych } \\
\text { - poziom dokładności projektów } \\
\text { - koszty działalności B+R } \\
\text { - wartość przychodów osiąganych ze sprzedaży nowych produktów } \\
\text { w ciągu przyjętego okresu } \\
\text { - wielkość sprzedaży osiąganej z nowych produktów na jednego pra- } \\
\text { cownika } \\
\text { - stopa zwrotu z inwestycji } \\
\text { - średnia liczba dokumentacji technicznej wykonanej przez jednego pro- } \\
\text { jektanta w danym okresie } \\
\text { - udziału kosztów projektowania i technicznego przygotowania produk- } \\
\text { cji w kosztach wytworzenia } \\
\text { - wskaźnik wykonania budżetu kosztów projektowania i technicznego } \\
\text { przygotowania produkcji } \\
\text { - wskaźnik błędów w procesie projektowania i w procesie technicznego } \\
\text { przygotowania produkcji }\end{array}$ \\
\hline \multicolumn{2}{|r|}{ Pomiar wyników procesu pomocniczego } \\
\hline Kontrola jakości & $\begin{array}{l}\text { - liczba kontroli wstępnych, międzyoperacyjnych, końcowych w danym } \\
\text { okresie } \\
\text { - udział wyrobów wadliwych w produkcji } \\
\text { - liczba kontroli na jednego pracownika procesu kontroli jakości } \\
\text { - wskaźnik wykonania budżetu służb kontroli jakości } \\
\text { - wskaźnik struktury kontroli jakości } \\
\text { - wskaźnik struktury wad wyrobów } \\
\text { - wskaźnik struktury kosztów jakości } \\
\text { - poziom nakładów na system zarządzania jakości } \\
\text { - liczba i koszty przeprowadzonych audytów wewnętrznych i zewnętrz- } \\
\text { nych } \\
\text { - liczba braków i napraw w poszczególnych procesach } \\
\text { - wskaźnik reklamacji }\end{array}$ \\
\hline
\end{tabular}


cd. tabeli 4

\begin{tabular}{|c|c|}
\hline Rodzaj procesu & Miernik oceny procesu \\
\hline \multicolumn{2}{|r|}{ Pomiar wyników procesu zarządczego } \\
\hline $\begin{array}{l}\text { Zarządzanie } \\
\text { finansami }\end{array}$ & $\begin{array}{l}\text { - czas i koszty konsolidacji danych } \\
\text { - skuteczność kontroli należności i zobowiązań } \\
\text { - produktywność personelu działu księgowości i analiz finansowych } \\
\text { - wsparcie podejmowania skutecznych decyzji na podstawie danych } \\
\text { ekonomicznych (zakres, koszty utrzymania i skuteczność wykorzysty- } \\
\text { wania systemów informatycznych) } \\
\text { - sprawność w dostarczaniu informacji, dokumentów dla kierownictwa } \\
\text { - czas opracowania sprawozdań finansowych } \\
\text { - obieg dokumentów (liczba dokumentów, liczba uczestników, czas } \\
\text { zapoznania się z dokumentacją) } \\
\text { - liczba pomyłek księgowych } \\
\text { - poziom wskaźników: płynności, rentowności, zadłużenia, wykorzysta- } \\
\text { nia majątku, wartości akcji } \\
\text { - poziom wykorzystania środków finansowych (struktura budżetów } \\
\text { poszczególnych procesów) } \\
\text { - dostęp do źródeł finansowania działalności oraz efektywność ich } \\
\text { wykorzystania } \\
\text { - dźwignia finansowa } \\
\text { - wartość zapłaconych odsetek z tytułu opóźnień }\end{array}$ \\
\hline
\end{tabular}

Źródło: opracowanie własne.

Zaproponowane miary dla procesów pozwalają w obiektywny sposób ocenić wyniki tych procesów. Zarządzanie procesami wymaga jasnego określenia celów i adekwatnych miar oceny dla poszczególnych procesów odbywających się w przedsiębiorstwie ${ }^{9}$. Wybrane mierniki powinny być pogrupowane w ramach kluczowych parametrów sukcesu przedsiębiorstwa, co jest konieczne w celu zapewnienia, że wyniki procesów są mierzone w kontekście obszarów uznanych przez kierownictwo za strategicznie istotne [Margheritta, Klein i Elia 2007, s. 46-57].

Pomiar procesów według ustalonego zestawu mierników może w pełny i systematyczny sposób oceniać czy przedsiębiorstwo osiąga przyjęte cele, czy efektywnie przekształca nakłady w efekty i pozwolić na kształtowanie aktywnie posiadanego systemu procesów. Dostarczanie cennych informacji o poszczególnych procesach do ich właścicieli (najczęściej w formie raportów) pozwala podjąć im decyzje o utrzymaniu poziomu realizowanych procesów lub zaproponowaniu zmian doskonalących procesy ${ }^{10}$.

${ }^{9}$ Uszczegółowieniem tej propozycji może być wykorzystanie pomiaru wyników procesów według koncepcji R. Kaplana i D. Nortona zawartej w strategicznej karcie wyników (BSC).

10 Pomiar efektów procesów w aspekcie ich skuteczności i efektywności powinien być dokonywany systematycznie, a rzeczywiste wartości mierników powinny być okresowo raportowane właścicielom procesów. 
Metodami niezwykle użytecznymi w ocenie procesów są audyt procesów i controlling procesów [Horowski i Kononowicz 2002, s. 34-37; Hoffman 2007, s. 225-267].

Etap 4. Doskonalenie procesów jest kolejnym etapem analizy procesowej. Po systematycznej analizie i ocenie procesów można zaproponować kierunki doskonalenia istniejących procesów. Doskonalenie polega na stałym poszukiwaniu możliwości ulepszania procesów w codziennej działalności, a także usprawnianie relacji między procesami. W konsekwencji doskonalenie procesów ma spowodować polepszenie jakości i (lub) produktywności, obniżyć koszty działań, a w ostatecznej ocenie przyczynić się do wzrostu efektywności całej organizacji.

Doskonalenie procesów w zmiennych warunkach funkcjonowania staje się wyzwaniem dla całej organizacji. Potrzebę tę wywołuje nieustanna konkurencja kosztowa, a także presja na podnoszenie szeroko rozumianej jakości. Doskonalenie procesów akcentowane jest w różnych koncepcjach i metodach zarządzania, między innymi w filozofii kaizen, zarządzaniu jakością, logistyce czy zarządzaniu wiedzą.

Rys. 5 zawiera etapy podejmowania decyzji o restrukturyzacji procesów w łańcuchu wartości przedsiębiorstwa.

Kierownictwo przedsiębiorstwa po uzgodnieniu z właścicielami procesów ${ }^{11}$ po dokonaniu oceny bieżącej sytuacji może podjąć decyzje o przeprowadzeniu doskonalenia procesów już istniejących w celu poprawy efektywności całego łańcucha wartości. Według S. Cyferta można wyróżnić dwa kryteria doskonalenia procesów w organizacjach:

1) kryterium ciągłości procesu doskonalenia, w ramach którego można zastosować dwa sposoby doskonalenia procesów:

- ewolucyjnego, czyli ciągłego doskonalenia procesów (to systematyczne, ciągłe usprawnianie istniejących $\mathrm{w}$ organizacjach procesów),

- radykalnego, czyli skokowego doskonalenia procesów (co oznacza, że procesy są w określonych odstępach czasu gruntownie odnawiane, tzn. projektowane są nowe procesy, radykalnie przeprojektowywane stare, stosowany jest też outsourcing procesów) [Procesy i projekty logistyczne, 2008, s. 77];

2) kryterium poziomów doskonalenia procesów, w ramach którego można wyróżnić dwa podziały:

- kryterium kompleksowości zakresu doskonalenia ${ }^{12}$,

- kryterium powiązania procesu doskonalenia ze strategią rozwoju organizacji [Cyfert 2006, s. 37-38].

11 Jako właścicieli procesów określa się osoby odpowiedzialne za przebieg i wyniki procesów.

12 W zakresie kompleksowości doskonalenia procesów jednym z kluczowych zagadnień jest pytanie: czy działania związane z doskonaleniem procesów powinny dotyczyć wszystkich procesów organizacji, czy też wybranych procesów. 


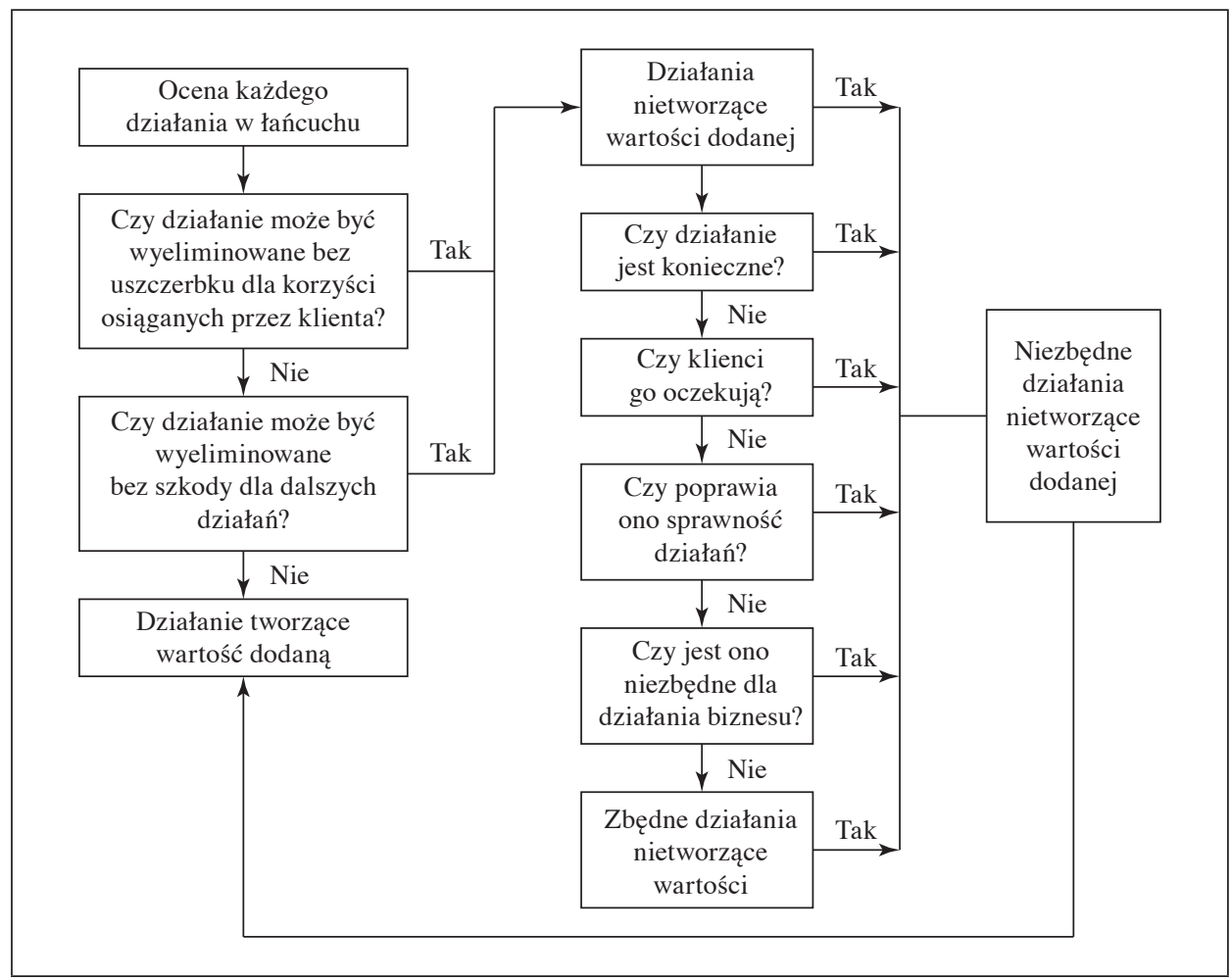

Rys. 5. Restrukturyzacja procesów w łańcuchu wartości przedsiębiorstwa Źródło: [Rokita 2005, s. 203].

Najbardziej znaną metodą radykalnego doskonalenia procesów jest reengineering. ${ }^{13} \mathrm{~W}$ związku z gwałtownością zmian, które towarzyszą tej metodzie, zaleca się jej stosowanie w sytuacji, gdy w otoczeniu organizacji zachodzą istotne zmiany lub zmiany mają miejsce $\mathrm{w}$ celach strategicznych organizacji [Procesy i projekty logistyczne, 2008, s. 79]. Wśród metod ewolucyjnego doskonalenia procesów na uwagę zasługuje filozofia kaizen symbolizująca ciągłą, systematyczną poprawę przebiegu procesu. Skierowana jest ona na określenie słabych ogniw, które obniżają skuteczność i efektywność procesów oraz na rozwiązywanie bieżących problemów.

13 Reinżynieria procesów biznesowych BPR (Business Process Reengineering) to koncepcja stworzona w 1990 r. przez M. Hammera, a w dalszej kolejności popularyzowana przez M. Hammera i J. Champy'ego [1996], J. Pepparda i P. Rowlanda [1997] oraz R. Manganelliego i M. Kleina [1998]. Współcześnie rozwinięciem koncepcji reinżynierii procesów jest X-engineering [Champy 2003]. 
W ramach kryterium powiązania doskonalenia procesów ze strategią rozwoju organizacji można wyróżnić:

- strategiczne doskonalenie procesów (w wyniku którego następuje dostosowanie procesów do modelu biznesu, który wynika z przyjętej strategii rozwoju),

- operacyjne doskonalenia procesów (oznacza silne dowartościowanie znaczenia pojedynczego celu lub zmierza do rozwiązania jednej, konkretnej dysfunkcji systemu zarządzania) [Cyfert 2006, s. 41].

Należy zauważyć, że operatywne doskonalenie procesów musi korespondować ze strategicznymi celami organizacji. Dlatego też za podstawowe kryterium podnoszenia efektywności i skuteczności procesów należy przyjąć strategię rozwoju przedsiębiorstwa.

Doskonalenie procesów uwzględniają także normy ISO z rodziny 9000: 2006 oraz koncepcje: TQM, lean management [Błoński i Kondracki 2004, s. 64], czy outsourcing [Gay i Essinger 2002, s. 12-15].

Tak więc kierunkami doskonalenia procesów w przedsiębiorstwie mogą być: przeprowadzenie reinżynierii procesów, ciągłe doskonalenie procesów, a także podejście mieszane [Skrzypek i Hofman 2010, s. 136] ${ }^{14}$.

\section{Zakończenie}

Łańcuch wartości tworzą rozwiązania w dziedzinie $\mathrm{B}+\mathrm{R}$, produkcji oraz organizacji przepływu produktów i informacji. Kształtują go oczekiwania klientów, uwarunkowania branży, kultura tworzących go firm oraz możliwości technologiczne. Presja na skracanie czasu reakcji wciąż rośnie i w sposób znaczący oddziałuje na wybory strategiczne i rozwiązania operacyjne w obszarze łańcucha wartości.

Analiza procesów składających się na strukturę łańcucha wartości pozwala na efektywne wykorzystanie posiadanych zasobów i umiejętności. W praktyce jest ona głównie wykorzystywana w badaniu mocnych i słabych stron organizacji i jej konkurentów. Jest niezwykle pomocna w podejmowaniu decyzji o współpracy z innymi firmami, a także w opracowywaniu nowych strategii wobec dostawców i odbiorców [Obłój 2002, s. 119-122].

${ }^{14} \mathrm{~W}$ ramach inicjowania, oceny i wdrażania zmian do procesu można wykorzystać metody i narzędzia służące do:

- analizy oraz optymalizacji procesów tj. wykres Ishikawy, histogramy, statystyczną kontrolę procesu, metodę analizy ścieżki krytycznej, metodę PERT, wykresy Gantta,

- eliminowania nieprawidłowości w procesie, tj. listy pytań kontrolnych, analizę ABC, drzewa zależności, burzę mózgów, skrzynkę morfologiczną, dyskusję 66, techniki oceny rozwiązania problemów: ankiety, wywiady, metody eksperckie [Romanowska 2001, s. 264]. 
Analiza procesów tworzących łańcuch wartości, poprzez określenie ich przebiegu, wzajemnych relacji, oceny poziomu skuteczności i efektywności ich realizacji, powinna prowadzić do etapu wyboru najkorzystniejszej struktury łańcucha wartości przedsiębiorstwa przynoszącej wzrost wartości dodanej.

\section{Literatura}

Biazzo S., Bernardi G. [2003], Process Management Practices and Quality System Standards. Risks and Opportunities of New ISO 9001 Certification, „Business Process Management Journal", nr 2.

Bitkowska A. i in. [2011], Zarzadzanie procesami w przedsiębiorstwie, Aspekty teoretyczno-praktyczne, Difin, Warszawa.

Blaik P. [2001], Logistyka. Koncepcja zintegrowanego zarzadzania, PWE, Warszawa.

Błoński M., Kondracki K. [2004], Zarzadzanie na przełomie wieków, Wydawnictwo Hays Personel, Warszawa.

Brilman J. [2002], Nowoczesne koncepcje i metody zarzadzania, PWE, Warszawa.

Champy J. [2003], X-engineering przedsiębiorstwa, Agencja Wydawnicza Placet, Warszawa.

Cyfert S. [2006], Strategiczne doskonalenie architektury procesów w zarzadzaniu przedsiębiorstwem, Wydawnictwo Akademii Ekonomicznej w Poznaniu, Poznań.

Cyfert S. [2012], Mechanizmy zarzadzania granicami - propozycja teoretycznego ujęcia $i$ wyniki badań empirycznych, „Współczesne Zarządzanie”, nr 3.

Drucker P. [1976], Skuteczne zarzadzanie. Zadania ekonomiczne a decyzje zwiazane z ryzykiem, PWN, Warszawa.

Edwards S.C., Braganza A., Lambert R. [2000], Understanding and Managing Process Initiatives: A Framework for Developing Consensus, „Knowledge and Process Management", vol. 7, nr 1.

Gay C.L., Essinger J. [2002], Outsourcing strategiczny, Oficyna Ekonomiczna, Kraków.

Gierszewska G., Romanowska M. [2003], Analiza strategiczna przedsiębiorstwa, PWE, Warszawa.

Hammer M. [1999], Reinżynieria i jej następstwa, Wydawnictwo Naukowe PWN, Warszawa.

Hammer M., Champy J. [1996], Reengineering w przedsiębiorstwie, Neumann Management Institute, Warszawa.

Handfield R. [1995], Reengineering for Time-based Competition, Benchmarks and Best Practices for Production. R\&D and Purchasing, Quorum Books, Westport Connecticut.

Hofman M. [2007], Controlling procesów w polskich przedsiębiorstwach, Annales UMCS, Sectio H Oeconomia, Wydawnictwo Uniwersytetu Marii Curie-Skłodowskiej, Lublin.

Horowski W., Kononowicz Ł. [2002], Strategia podnoszenia wartości przedsiębiorstwa w zarzadzaniu procesami, „Controlling i Rachunkowość Zarządcza”, nr 5.

Kale V. [2001], SAP R/3. Przewodnik dla menadżerów, Helion, Gliwice.

Kaplan R.S., Norton D.P. [2002], Strategiczna karta wyników. Jak przełożyć strategie na działanie, Wydawnictwo Naukowe PWN, Warszawa. 
Kotler Ph. [2005], Marketing, Dom Wydawniczy Rebis, Poznań.

Lisiecka K., Czakon W. [2002], Aspekt ekonomiczny integrowania łańcucha wartości (na przykładzie sektora ciepła systemowego), Prace Naukowe Akademii Ekonomicznej we Wrocławiu, nr 928, Wrocław.

Logistyka. Teoria i praktyka [2011], red. S. Krawczyk, Difin, Warszawa.

Łańcuch tworzenia wartości dodanej przedsiębiorstwa [2007], red. B. Woźniak-Sobczak, Prace Naukowe Akademii Ekonomicznej w Katowicach, Katowice.

Manganelli R., Klein M. [1998], Reengineering - metoda usprawnia organizacji, PWE, Warszawa.

Margherita A., Klein M., Elia G. [2007], Metrics-Based Process Redesign with the MIT Process Handbook, „Knowledge and Process Management”, vol. 14, nr 1.

Muller R., Rupper P. [2000], Process Reengineering, Wydawnictwo Astrum, Wrocław.

Nowak E., Piechota R., Wierzbiński M. [2004], Rachunek kosztów w zarzadzaniu przedsiębiorstwem, PWE, Warszawa.

Obłój K. [2002], Tworzywo skutecznych strategii, PWE, Warszawa.

Olszewska K. [2003], Reorientacja na procesy a kryzys przedsiębiorstwa [w:] Zachowania organizacji wobec zjawisk kryzysowych, red. J. Skalik, Wydawnictwo Akademii Ekonomicznej we Wrocławiu, Wrocław.

Peppard J., Rowland P. [1997], Re-engineering, Gebethner i Spółka, Warszawa.

Porter M.E. [2006], Przewaga konkurencyjna. Osiaganie i utrzymanie lepszych wyników, Wydawnictwo Helion, Gliwice.

Porter M.E. [1985], Competitive Advantage. Creating and Sustaining Superior Performance, The Free Press, New York.

Procesy i projekty logistyczne [2008], red. S. Nowosielski, Uniwersytet Ekonomiczny we Wrocławiu, Wrocław.

Rokita J. [2005], Zarzadzanie strategiczne, tworzenie przewagi konkurencyjnej, PWE, Warszawa.

Romanowska M. [2001], Podstawy organizacji i zarzadzania, Difin, Warszawa.

Rummler G., Brache A. [2000], Podnoszenie efektywności organizacji, PWE, Warszawa.

Skrzypek E. [2002], Jakość i efektywność, Wydawnictwo Uniwersytetu Marii Curie Skłodowskiej, Lublin.

Skrzypek E., Hofman M. [2010], Zarządzanie procesami w przedsiębiorstwie, Identyfikowanie, pomiar, usprawnianie, Oficyna a Wolters Kluwer business, Warszawa.

Sopińska A. [2004], Procesowa organizacja przedsiebiorstwa [w:] Procesowe podejście w zarzadzaniu TQM, red. M. Romanowska, M. Trocki, Szkoła Główna Handlowa, Warszawa.

Stabryła A., Zarzadzanie projektami ekonomicznymi i organizacyjnymi, Wydawnictwo Naukowe PWN, Warszawa 2006.

Stabryła A. [2007], Zarzqdzanie strategiczne w teorii i praktyce firmy, Wydawnictwo Naukowe PWN, Warszawa-Kraków.

Strategiczne zarzadzanie kosztami [2006], red. E. Nowak, Oficyna Ekonomiczna, Kraków.

Zarzadzanie procesami biznesowymi. Aspekt metodyczny [2009], red. J. Czekaj, Uniwersytet Ekonomiczny w Krakowie, Kraków. 


\section{An Analysis of the Processes Shaping the Value Chain in Enterprise}

Today's enterprises are forced to identify and change the whole chain of value creation for the customer, which usually extends beyond its borders. An important stage in the analysis of an enterprise's value chain is identifying the processes carried out in the organisation and evaluating how effectively and efficiently they are achieved, which is possible by establishing and developing specific measures and methods of measuring these processes.

The purpose of this article is to provide a method for increasing the value of the enterprise, based on the analysis of processes involved in the enterprise's value chain. The paper explains the basic concepts of process, system processes and process management, defines the value chain and shows the structure of the processes that shape it.

The main part of the article presents the methodology of the analysis process, which consists of the following stages: identifying the processes carried out in the enterprise, indicating the role of the processes in creating added value for the customer, measurement and evaluation of the results of processes, and determining process improvement proposals.

Keywords: process, process management, process analysis methodology, value chain, value chain structure. 